\title{
THE INLAND WATERWAYS OF GREAT BRITAIN AND THE PLANS UNDER CONSIDERATION FOR THEIR IMPROVEMENT
}

\author{
By URquhart A. Forbes, Esq., \\ London, England.
}

\section{Extent of the British Inland Navigation System}

The total extent of the waterways of Great Britain and Ireland, as stated in a Return of the Board of Trade, 1898 , which is the latest official record on the subject, is 3,906 miles $691 / 4$ chains, the mileage of those in England and Wales being returned as 3,167 miles $161 / 4$ chains, that of those in Scotland 153 miles 21 chains, and that of those in Ireland 586 miles 32 chains. This estimate, however, can only be taken as approximately correct. It omits various waterways of which no official record has been preserved, such as Milford Haven, one of the finest harbors in the kingdom, which has between twenty and thirty miles of inland navigation; and it also differs considerably both from an earlier estimate of the board published in 1883 and from the estimates of various engineers who are recognized as authorities on the subject. The discrepancy between these various estimates appears to be mainly due to the omission from some of the waterways included in others and does not extend to mileage, and a comparison of their details with those given in the Board of Trade Return of 1898 shows that, after deducting 607 miles of waterway abandoned or converted into railway, the inland navigation system of the kingdom comprises about 3,793 miles in England and Wales, 341 in Scotland, and 629 in Ireland-a total of 4,764 miles. The estimates on which this conclusion is based are given in the subjoined table. ${ }^{1}$

IO the following estimates, those of Mr. Couder, C.E., Mr. Taunton, C.E., and Mr. Lloyd, C.E., were prepared for the select committee on canals, 1883; that of Mr. Wells, C.E., for the Birmingham Conference, 1898, on Inland Navigation, organized by the Institution of Mining Engineers; and that of the late Mr. Vernon Harcourt, C.E., is contained In a paper on the subject read before the Soclety of Arts, 1899. To these might be added, did space permit, an estimate of the Irish waterway system contalned in the report of a commission on the subject, of 1882, whlch gives the total extent as 708 mlles, 20 chains:

$(228)$ 


\section{Character and Development of the System}

The bases of this system have in each of the three kingdoms been supplied by their numerous navigable rivers, which, owing to the neglected state of the roads after the decay of the old Roman highway system, formed the principal means of transport until the introduction of the turnpike roads. The tidal coast line of Great Britain is 3,900 miles in extent and greater than that of any other country in Europe, and, as has been pointed out by the late $\mathrm{Mr}$. Vernon Harcourt, the tidal wave which traverses the British coasts places these rivers, which, owing to their small drainage areas, would otherwise be of no value for ocean navigation, on a par with the largest of those of other countries. The Thames, for instance, with a basin of $\mathrm{I}-82$ that of the Danube, affords superior facilities for navigation at high water between the sea and London to that of the Sulina mouth. The Mersey, with a basin only $1-722$ that of the Mississippi, is as accessible at high tide up to Liverpool as the South Pass. The navigable channel of the Usk, the basin of which is only I-888 that of the Volga, has nearly double the depth, at high water of fair neap tides, of the most favorable Volga outlet, and about three times the present available depth in that river from the Caspian Sea up to Astrakhan. The Ribble is of more use for navigation than the Rhone, though its basin is only I- 58 that of the latter river; and in earlier times this tidal wave penetrated much further inland and the navigation of the rivers flowing into the Wash was so good that as late as 1649 the now

\begin{tabular}{|c|c|c|c|}
\hline & $\begin{array}{l}\text { Board of Trade. } \\
\text { Return } 1883 .\end{array}$ & $\begin{array}{l}\text { Mr. Gouder. } \\
1883 .\end{array}$ & $\begin{array}{l}\text { Mr. Taunton. } \\
1883 \text { [Erigland, wales } \\
\text { and Scotland only]. }\end{array}$ \\
\hline England and Wales & 2688 & $\left\{\begin{array}{l}4333 \\
1878 \text { Feeders. }\end{array}\right.$ & $\left\{\begin{array}{r}2451 \\
371 \\
\text { derelict. }\end{array}\right.$ \\
\hline $\begin{array}{l}\text { Scotland ......... } \\
\text { Ireland. . . . . }\end{array}$ & $\begin{array}{r}85 \\
256 \\
\end{array}$ & $\begin{array}{l}354 \\
755\end{array}$ & \\
\hline Total ........... & 3020 & 7320 & 3012 \\
\hline & $\begin{array}{l}\text { Mr. Tloyd. } \\
1883 \text { [Fngland } \\
\text { and Wales]. }\end{array}$ & $\begin{array}{l}\mathrm{Mr} \text {. Wells. } \\
1895 \text { [England } \\
\text { and Wales]. }\end{array}$ & $\begin{array}{c}\text { Mr. Vernon Harcourt. } \\
1890 .\end{array}$ \\
\hline England and Wales & \multirow{2}{*}{$\begin{array}{l}3742 \\
308 \text { derel }\end{array}$} & \multirow{2}{*}{ ct. $\left\{\begin{array}{r}3920 \\
415\end{array}\right.$ derelict. } & $\mathbf{3 3 7 4}$ \\
\hline $\begin{array}{l}\text { Scotland ......... } \\
\text { Ireland. . . . . }\end{array}$ & & & $\begin{array}{r}120 \\
610 \\
\end{array}$ \\
\hline Total $\ldots \ldots \ldots \ldots$ & 4050 & 4335 & $\overrightarrow{4106}$ \\
\hline
\end{tabular}

To these estimates may be added that of Mr. Rudolph de Salis for Fingland and Wales as given In Bradshaw's Canals and Navigable Rivers of England and Wales, where the mileage for those countries is given as 3,915 mlles, 842 mfles of which are tidal and 3,073 non-tidal. 
insignificant port of Lynn supplied six counties wholly and three partially with imports from the continent.

\section{Early Developments}

During the seventeenth century this system of natural waterways was developed by a series of acts of Parliament empowering private individuals and bodies of individuals to improve the navigation of rivers and to make others not previously so, navigable. This movement was followed by the initiation by Brindley in I795 of what may be termed the "canal era," during which all the navigable rivers of the kingdom were gradually connected with each other by means of a network of canals constructed by private enterprise in order to provide for the needs of different localities. In England and Wales the development of inland navigation, which began in 1423 with an act for removing obstructions in the Thames, may be said to have practically ended with the completion of the Manchester Ship Canal in I894, and has thus extended over four and a half centuries. In Ireland it began only in 1715, with the improvement of the Maigue River, and ended with the completion of the Ballinamore Canal in 1859 ; and in Scotland it was linited to the eighty-eight years between the passing of the first Clyde improvement act in 1759 , and the completion of the Caledonian Canal in 1847 .

\section{Varieties of Waterways}

It has, however, proceeded on the same lines in each of the three kingdoms, the inland navigation systems of each of which include the three following varieties of waterway:

(I) Tidal navigable rivers, the soil of the bed of which is vested in the Crown for the benefit of the public, and on which all the subjects of the Crown enjoy the right of free navigation.

(2) Nontidal rivers which have been made navigable, and tidal rivers the navigation of which above the tideway has been improved under an act of Parliament, the ownership of the soil of which is, in both cases, for the purposes of navigation only, vested in commissioners or conservators appointed under the act who are entitled to demand tolls for the use of the river, which are devoteil solely to the maintenance of the navigation.

(3) Canals constructed by private enterprise by companies 
incorporated under special acts, who are the sole owners of their respective undertakings and are entitled to all the profits accruing from the tolls payable under these acts by the public for their use.

\section{State Ozonership and Control}

In England and Wales state ownership of waterways is limited to the soil of the bed of tidal rivers, as above mentioned, and the state has never contributed in any way to the development of water conservancy. In both Scotland and Ireland, however, it has not only made large grants from the treasury for this purposethe total expenditure on the Caledonian Canal in the former country, for instance, amounted to $\pm_{1}, 280,000$, and the grants for the

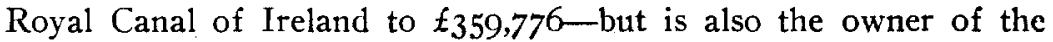
Caledonian Canal (constructed entirely by it) and the Crinan Canal in Scotland and of the Maigue, Boyne, Tyrone and Shannon River navigations in Ireland, where it also originally owned both the Grand and the Ulster Canals. The Board of Trade is the central authority for the control of inland navigation, and has the power of providing for the inspection of waterways, the condition of which is dangerous to the public, or liable to cause obstruction to traffic, and for their transfer to local authorities, or, if necessary, their abandonment. English canal companies are also required to send to the registrar of joint stock companies annual returns stating the address of the office and principal officers of the company; and the governing authorities of all waterways are under the obligation of furnishing the Board of Trade, when required to do so, with particulars respecting their works, capacity for traffic and capital, revenue, expenditure and profits. ${ }^{2}$ The Caledonian and Crinan Canals in Scotland are controlled by commissioners appointed by the Crown, and those owned by the state in Ireland by the commissioners of public works in that country, and both of these bodies report annually to Parliament.

\section{Conservancy Authorities}

The governing bodies of the different waterways comprised in the British inland navigation system vary very greatly both in size and constitution, and in addition to the canal companies include bodies of conservators, commissioners, port and harbor authori-

2This power has been exercised by the board only twice slnce it was first conferred on it by the Rallway and Canal Traffic Aet, 1888. 
ties and municipal corporations. The conservancy authorities of a few of the more important rivers are of a representative character. The conservators of the River Thames, for instance, are thirty-eight in number and include representatives of the Admiralty and two other government departments, of the city and the county of London, of the London Water Board, and of the county or borough councils of the eleven counties traversed by the river. The thirty commissioners of the Severn represent the counties of Gloucestershire and Worcestershire, and the corporations of all the towns on the banks of the river from Bristol to Wenlock in Salop, while the tidal portions of both the Mersey and the Clyde are controlled by trusts on which the municipalities of Liverpool and Glasgow are largely represented, as well as the conservators of the navigation of those rivers.

\section{Groups of Waterways in England}

The waterways of England and Wales are divisible into six groups, one of which has its center in Birmingham, while the other five unite wholly or partially in the estuaries of the Humber, Mersey, Wash, Thames and Severn. The Thames and Severn are united by 648 miles of waterway; the Thames and Humber by 537 miles; the Severn and Mersey by 832 miles and the Mersey and Humber by 680 miles, while the ten waterways flowing into the Wash have an extent of $43 \mathrm{I}$ miles. London is connected with Liverpool by three through routes, with Hull by two and with the Severn ports by four; Liverpool with the Severn ports by two, with Hull by three, with the South Staffordshire mineral districts by two; and the last named districts with the Severn ports by three routes. Though, however, nine of these nineteen through routes terminate in the Severn ports and mine in London as against ten in Liverpool and five in Hull, the southern waterways are now of far less importance than those of the northern counties. No less than $23,500,000$ tons of $37,426,886$ which according to the Board of Trade returns, 1898 , was the total traffic on English and Welsh waterways in that year, was concentrated round an area bounded by the Birmingham and Shropshire Union Canals, the Leeds and Liverpool Canal, the Aire and Calder Navigation, the Don Navigation, a line from Sheffield to Stoke. and the Trent and Mersey Navigation-a mining and manufacturing district, the waterways of 
which have a united length of only 642 miles. The traffic of the Birmingham canals amounts to $7,750,000$ tons; that of three other systems of waterways within this area to between $2,000,000$ and 3,000,000 tons; that of three to between $1,000,000$ and 2,000,000 tons; and that of seven to between 500,000 and $1,000,000$ tons. Only three waterways within this district have less than 100,000 tons traffic, but the Grand Junction Canal is the only waterway extending into the southern counties which has a traffic exceeding I,000,000 tons, and only three (the Stafford and Worcester Canal, the River Lea and the Thames between Oxford and London) have a traffic exceeding 500,000 tons.

\section{Scottish Waterways}

In Scotland, though the Tay-navigable for 95 miles up to Perth for vessels of 200 tons-the Tweed and the Dee have been utilized for purposes of navigation, the Clyde and the Forth are the only two navigable rivers of importance. The country possesses only five canals, two of which, the Caledonian and the Crinan, though remarkable as engineering works, have proved of little value for purposes of trade, and in 1898 , when the total traffic amounted to only $\mathrm{r}, 223,304$ tons, the only waterways having a traffic exceeding Ioo,000 tons were the Forth and Clyde Navigation and the Edinburgh and Glasgow Union Canals. Scotland, however, possesses special advantages as regards inland navigation in the extent and number of its navigable lakes and in the fact that the firths of its two principal rivers-the Forth and the Clydeare not separated by any range of hills and penetrate the plain between them on opposite sides, dividing the country, the breadth of which is there reduced to 50 miles, into halves.

\section{Irish Waterways}

Ireland, which, like Scotland, has numerous large navigable lakes, has an excellent system of waterways, which comprises both the longest river and one of the most extensive canals in the United Kingdom-the Shannon, 143 of the 256 miles of which are navigable, and the Grand Canal, which is 163 miles long and has ten branches. Owing, however, probably to the absence of manufacturing and mining industries in the country, the total traffic in 1898 amounted to only $708,174 \% / 4$ tons, 309,288 tons of which was con- 
centrated on the Grand Canal, which, with the Lagan Canal, witl a traffic of 171,784 tons, are the only two on which the traffic exceeded 100,000 tons, while the Shannon, with 83,688 tons, was the only waterway on which it exceeded 50,000 tons.

\section{Principal Rivers of the United Kingdom}

The rivers of the United Kingdom with the greatest extent of navigation are the Thames, 215 miles long, which is navigable for I 45 miles; the Severn, about two-thirds of the 200 miles of which are navigable; the Shannon, navigable for 143 miles out of its total length of 256 miles, and the River Forth, in Scotland, which, though only 72 miles long, is navigable for 50 miles. The short tidal navigations of the Tyne, Wear, Tees and Humber, on the east side of the Clyde, Mersey, Ribble and Bristol Avon on the west coast, though none of them much exceed 20 miles in length, are, however, of far greater importance for commercial purposes.

\section{The Manchester Ship Canal}

The most important of the British canals, both commercially and from an engineering point of view, is the Manchester Ship Canal, begun in 1885 and opened for traffic on May 21, I895, on which $\chi_{15}, 173,402$ was expended-a total which included $\ell_{I}, 786$,3 I 3 paid for the Bridgwater Canal and $\sum_{I}, 2$ I $4,45 I$ for compensation paid to various bodies possessing vested interests in the land it traverses. The canal, which is $35 \mathrm{~T} / 2$ miles long and from which no less than $53,000,000$ cubic yards of soil were excavated, ${ }^{3}$ consists of three sections. The first of these runs from Eastham to Runcorn, near or through the Mersey estuary, a distance of 123/4 miles, and is provided with three tidal locks with chambers 600 feet by 80 feet, 350 feet by 50 feet, and 150 feet by 30 feet, with sills 28 feet, 25 feet and 16 feet, respectively, below the normal water level of the canal. The second section runs from Runcorn to Latchford, near Warrington, $8 \mathrm{I} / 2$ miles, where it is inland, but in which the level of the water as in the first section is raised by the tides; and the third from Latchford-where the locks stop the tidal action and the canal is fed by the Mersey and Irwell up to Manchester. One of the most notable features of the work is the swing aqueduct for the Bridgwater Canal, the first of its kind,

\footnotetext{
3Ninety-seven excavators. eight large bucket ladder dredgers and fifty-elght steam navvies were employed on the work besides some small dredgers.
} 
by means of which, when closed, traffic can pass along the latter canal as heretofore, but which can be opened to allow of ships crossing it on the lower level of the ship canal. This aqueduct, constructed by Sir E. Leader Williams to replace that built by Brindley 136 years previously, was the first fixed aqueduct constructed in the United Kingdom. It may be added that the Manchester Ship Canal is the first large ship canal constructed with locks raising vessels $60 \mathrm{~T} / 2$ feet and transporting them inland.

\section{The Caledonian Canal}

Though it failed to realize the main objects for which it was constructed, the Caledonian Canal, having regard to the physical difficulties overcome in its construction and the period at which it was made, must be regarded as being scarcely less remarkable as an engineering feat than the Manchester Ship Canal. Its length is 60 miles, $37^{1 / 2}$ miles of which consist of four naturally navigable freshwater lochs connected by a series of canals 23 miles in length, and it extends diagonally across Scotland from Fort William on the Atlantic to Clachnaharry on the shore of Beauly Firth on the North Sea, and thus provides a means of enabling vessels to avoid the dangers and delays incident to the 500-mile voyage by the Orkneys and Cape Wrath. There are docks both at Corpach and Clachnaharry, the latter of which cover an area of 32 acres, and one of its most remarkable features is a series of eight connected locks, called by Telford "Neptune's Staircase," constructed to overcome the difficulty caused by the difference in the levels between Lochs Lochy and Eil, which, though the distance is only 18 miles. amounts to 90 feet. The canal is one of the finest monuments of Telford's genius, and is also notable as the only British waterway which has been constructed entirely at the cost of and has always remained under the control of the state.

\section{The Grand Canal of Ireland}

The total expenditure by the state on the Caledonian Canal was $£ 1,300,000$ and it also contributed $£_{321,674}$ out of the $\varepsilon_{1,370,-}$ ooo expended on the Grand Canal in Ireland, which is the most important waterway in that country, and though its total length of 163 miles is exceeded by that of the Shropshire Union, which is 200 miles long, it is, as has been said, the most extensive water- 
way in the United Kingdom. It extends southwards from Dublin to New Ross in Wesford and westward to the Shannon Harbor, where the trade boats of the company transship into steamers plying northwards to Athlone and southwards to Limerick, while on the other side of the Shannon it runs to Ballinasloe and has no less than ten branches connecting it with the Liffey and various trading centers.

\section{Other English Canals and Their Earnings}

Among other English canals the next in length to the Shropshire Union are the Grand Junction, I 88 miles long; the Birming. ham canals, with a united length of 158 miles, and the Leeds and Liverpool Canal, I4I miles long. The Birmingham canals had, according to the Board of Trade returns, I898, the highest net

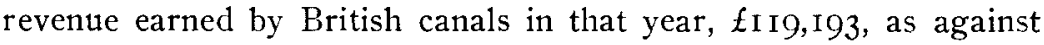
$\{103,663$ earned by the Manchester Ship Canal; while the third waterway on the list was the Aire and Calder Navigation, which, though only 85 miles long, had a net revenue of $\pm 92,057$, as against $£ 50,642$ earned by the Leeds and Liverpool, $£_{4} 8,840$ earned by the Grand Junction, $t 23,613$ by the Grand Canal, Ireland, and only $f_{1,099}$ by the Shropshire Union. The Aire and Calder and the Weaver are the two most remunerative of the river navigations of the country, and over $I, 000,000$ tons of salt, besides a considerable trade with the potteries in coal, timber, cotton, flint and clay are annually carried over the latter river, which has been canalized for 50 miles between Northwich and Chester, and has four large locks 220 feet long by 42 feet 6 inches wide, and having 15 feet of water on the sills.

\section{Financial Position of British Waterway's and Its Causes}

As will be evident from the above figures, a large portion of the inland navigation system of the United Kingdom, on which $f_{14}, 000$,000 had been expended up to 1830 , has ceased to be remunerative. No less than 39 out of the 99 waterways of England and Wales were shown by the return of 1898 to be carried on at loss, and of the 126 waterways in the United Kingdom only two earned net incomes exceeding $£ 100,000$. Only twelve waterways

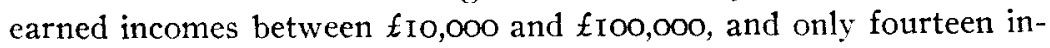

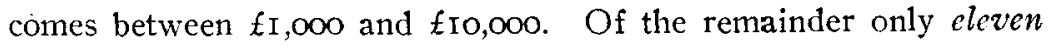


earned incomes exceeding $\mathfrak{t 5}_{500}$; and, though the impoverished condition of the canal companies and navigation authorities is partly due to the defective and obsolete construction of a majority of the waterways, the number of conflicting authorities by which they are governed and the keen competition between them, it is primarily attributable to the extensive control which the railway companies have acquired over the whole of the inland navigation system.

\section{Railway Control}

This control was first acquired by the railway companies at the time of the "railway mania" of 1845 , when not only the public, on whose investments the canal companies depended for support, but also the companies themselves appear to have simultaneously concluded that water transport was about to be permanently superseded by the new invention. Though some of the canal companies were still paying dividends of 25,26 and 30 per cent, many of them put pressure on the railway companies to purchase their undertakings, and by the end of 1846 the latter bodies had acquired possession of 944 miles of waterway; the ownership of nearly onethird of the waterways in England and Wales; one-fourth of those in Scotland, and more than one-sixth of those in Ireland is now divided between thirteen railway companies in England and Wales, two in Scotland, and one in Ireland. Where a railway company owns an entire canal it can regulate the traffic for the benefit of its railway, and where it owns only a portion of it, it can fetter the traffic on the other portions; and as almost every through water route has links in it under the control of a railway company, the railway companies, each of which exercises sole control over its own through route, are enabled to manipulate the traffic on the majority of waterways as they please. By charging excessive tolls, keeping their canals narrow, and making rules to fetter traders who attempt to convey their goods entirely by water, they have induced what the late Mr. Couder, R.E., termed a state of "creeping paralysis" among canal companies, the impoverished condition of which, in a majority of cases, renders it impossible for them to attempt the improvements necessary to enable them to compete with their wealthier rivals. 


\section{Defective Condition of Waterways}

Owing to the neglect of inland navigation for over threequarters of a century, the greater number of canals still retain their original form of construction and are practically enlarged ditches, with a top water of about 30 feet and a bottom of 14 feet and with inclined slopes on either side-a form which produces a tendency to fill up at the bottom, with a consequent variation in the depth of the waterway in different canals, which is a serious impediment to traffic. In many cases both the locks and the canals themselves are too narrow to allow boats to pass each other properly, while throughout Great Britain, and especially in England and Wales, there are scarcely two canals that have a common gauge, and in some cases two or three different gauges of locks are to be foun 1 upon the same canal. Only 20 per cent of the independent waterways can admit craft that would enable them to realize the full value of economical transport. While there are 1,240 miles of canals designed for boats carrying cargoes of from 18 to 30 tons, and Calder and the Weaver, have been sufficiently enlarged and and 2,040 miles adapted for boats carrying cargoes of 40 to 60 tons, there are only 230 miles of waterways which, like the Aire, are improved to accommodate boats carrying from 90 to 350 tons. Some of the waterways under public trusts, and especially the more important rivers, such as the Thames, Severn, Lea, Clyde, Forth and Shannon, have been considerably improved, but the majority of these are much in the same position as those dependent upon private enterprise.

\section{Defects of Organization and Competition}

In addition to the two causes which have just been discussed, waterways have suffered from the want of enterprise and of the capacity for concerted action among canal companies, to which the railway companies largely owe their success, and from the number of conflicting authorities by which the majority of river navigations are governed. While the ownership of 22,455 miles of railway in the United Kingdom is shared between some thirtyeight companies, each of which governs its own through route, that of the 3,321 miles of waterway which remain independent of railway control is divided amongst more than double that number of canal companies and navigation trustees. Not one of the ninc- 
teen through routes by water in England and Wales has the advantage of being under a single body. There are, including the authorities of the navigable tideways such as the Mersey, Severn and Humber, twenty-six different bodies which compete with each other on the three through routes connecting London and Liverpool. There are twenty-seven on the four between London and Bristol, ten on the three between Birmingham and Bristol, and the same number on the three between $\mathrm{Hull}$ and Liverpool. The commissioners of the Severn control only 42 miles of its total length of 250 miles and the only conservancy authority on the Trent, which is 167 miles, exercises jurisdiction over only 73 miles: but the 57 miles of the Kennet and Avon are controlled by four different authorities, the $3 \mathrm{I}$ miles tidal portion of the Nen by eight public bodies, and the Witham, which is between 80 and 90 miles long, by seventeen different sets of commissioners. Water transport in the United Kingdom is, therefore, seriously impeded both by the defective administration arising from this multiplicity of authorities and also by the keen competition for traffic between the canal companies, which have hitherto entirely ignored the facilities offered to them under the Railway and Canal Traffic Act, I888, for establishing a clearing system analogous to that which has so greatly benefited the British railway companies.

\section{Revived Interest in Inland Navigation}

The defective condition of British waterways has long been generally recognized, and during the last quarter of a century there has been a revival of public interest in the subject as well as in those of water supply, fishery and other kindred branches of water conservancy.

Inland navigation has been discussed from time to time by bodies like the Institution of rivil Engineers, the Society of Arts and the Associated Chambers oi Commerce of the United Kingdom, and more especially at the meeting of the British Association at Dublin in 1878 , and at conferences organized by the Society of Arts in London in I888, and by the Institution of Mining Engineers at Birmingham in 1895. A very valuable paper, for which the Telford gold medal was awarded, was read before the Institution of Civil Engineers, in May, 1905, by M. J. A. Sauer, M. Inst. C. E.. in which he advocated that main trunk canals should be constructed 
for conveying cargoes of not less than 250 to 300 tons at a time for the more important cross-country routes, with locks, 230 feet by 22 feet, with 6 feet 6 inches water on the sills, and vertical lifts I 3 feet by 17 feet, with 6 feet 6 inches where required. "The Improvements required in Inland Navigation," also formed the subject of a paper, by Henry Rudolph de Salis, Asso. M. Inst. C. E., read at the general meeting at London of the Institution of Mining Engineers on June 15, 1907, in which the author, who has personally inspected the whole of the inland navigations of England and Wales, urged that the primary essentials for their improvement are the selection of such as are likely to repay development, and the reorganization of the authorities controlling them. Various "canal projects," none of which, however, have yet been adopted, have been from time to time placed before the public-such as the construction of a national canal capable of accommodating steam barges to connect the Thames and the Mersey; ${ }^{*}$ ship canals, connecting Goole and Sheffield, and between the Mersey and Birmingham; a canal connecting Birmingham with the Trent and the North Sea; and an improved waterway between the Midlands and the Thames. The revived interest in waterways has also borne practical fruit in the construction of the Manchester Ship Canal, the most important event in the history of British waterways since the opening of the Bridgwater Canal-the success of which has itself tended to encourage canal enterprise. It has been evidenced by the amalgamation, in I894, of the Berkley Ship Canal and three other inland canals ${ }^{8}$ under the Sharpness New Rocks and Gloucester and Birmingham Navigation Company, and by a similar amalgamation in Ireland of the Ulster, Coal Island and Lagan canals under the Lagan Navigation Company. Its influence may also be traced in the purchase, about the same time, of the Grand Union of Leicester and the Northants Union canals by the Grand Junction Canal Company, and by the acquisition by that canal, by arrangement of tolls between Birmingham and London, and in the purchase, in 1895 , by the Sheffield and South Yorkshite Navigation Company from the Manchester and Sheffield Railway Company,

Adrocated by Mr. S. Lloyd, C.E., in a pamphlet published in 1885. Weaver.

sConnecting with the Manchester Shlp Canal and the Mersey by way of the

The Worcester and Birmlngham, Droltwich Junction, and Droltwich Canals. 
of the Don Navigation, which connects Sheffield, Rotherham, Barnsley and Doncaster with the Trent at Keadby and the Ouse at Goole. In addition to this, public interest in the question has been shown by the passing, as early as 1882 , of a resolution at the annual meeting of the Associated Chambers of Commerce advocating the entire emancipation of canals from the control of railway companies, and during recent years by a series of such resolutions passed both by individual chambers and by the Associated Chambers of Commerce of the United Kingdom in favor of the nationalization of waterways.

\section{Associated Chambers of Commerce and Nationalization of Waterways}

The most important resolution on the latter subject was one passed at the annual meeting of the Associated Chambers at Manchester on December 4,.1904, that:- "in view of the urgent necessity of cheapening the cost of the internal transit of goods," and of the benefit to the community that must accrue from the development of inland navigation, "this association, being of opinion that the best results can only be obtained through unity of management, strongly urges that the waterways of the United Kingdom should be acquired by the state or by a suitably constituted national trust." This resolution, which was submitted by the Liverpool and Manchester chambers-both of which had in 1882 declined to sign the resolution in favor of emancipating canals from railway control-was subsequently modified by the addition that there should be a "government guarantee, supervision and control of any national trust constituted for the purpose, and in this form was supported by sixty-one and opposed by forty of the Chambers represented, but was rendered ineffective by the fact that a twothirds majority had not been obtained in its favor. As, however, the association had similarly advocated the compulsory purchase of canals by the government at five of its meetings, and resolutions to this effect have been since 1904 passed by various provincial chambers and discussed by the London Chamber of Commerce, it is evident that there is a substantial body of public opinion in favor of the suggestion. 


\section{The Canal Trusts Bill, I905}

The principle of the second portion of the Manchester reso. lution was subsequently embodied in the Canal Trusts Bill, 1905, which was introduced into Parliament by Mr. Rowland $\mathrm{H}$. Bowan, the Liberal member for North Leeds, for the establishment of a canal trust "to acquire, develop, and extend and administer in the public interest canals and navigations in England and Wales. This measure, which was supported by thirteen members, belonging to the three political parties in the House of Commons and representing constituencies in the northern and midland counties, Scotland and Ireland, proposed to incorporate a body of twenty-nine trustees, twenty-one of whom were to be appointed by the treasury and other government departments, and the remaining eight by various port authorities, Chambers of Commerce and other kindred associations. This body was to be empowered to purchase the Birmingham and twelve other canals and two river navigations for the purpose of organizing a through system of communication between London, Liverpool, Hull and Bristol, and also subsequently to acquire other canals and navigations by agreement or by a provisional order from the Board of Trade. Owing, however, to the neglect of its promoters to comply with the regulation requiring bills of this description to be advertised in the London Gavette this measure had to be withdrawn before Parliament had had the opportunity of pronouncing an opinion upon it.

\section{The Respective Merits of "Nationalization" and "Canal Trusts"}

"Nationalization" and "Canal Trusts" may be said to be the only two schemes for the improvement of British waterways which at present find favor with the public. The first, though theoretically attractive, is open to the objections that it is likely to be opposed by the more prosperous canal companies, and, which is more important, that Parliament is not likely to be favorably disposed to a plan entailing a very heavy expenditure for the acquisition of waterways, the capacity of which for yielding a revenue sufficient for their upkeep is, to say the least, extremely problematical. Canal trusts are also, no doubt, likely to be opposed on the grounds that they interfere with the rights of private enterprise and necessitate the grant of public money for an uncertain object; but they 
have the merits of providing for the transfer of the control of our waterways from a number of competing bodies to a representative central authority, and of being organizations capable of tentative introduction and gradual extension.

\section{Extension of the Powers of the Board of Trade}

In default of the adoption of either of these schemes, much might be effected in the improvement of British inland navigation by an extension of the supervisory powers of the Board of Trade, which is the central authority for waterways, if canal companies and navigation authorities would adopt the principle of cooperation in lieu of that of competition, and like the railway companies, endeavor to fit their respective undertakings for through traffic by the establishment of a minimum gauge for waterways and locks and of standard traffic rates. It must, however, be added that, as has been pointed out by the present writer and his coauthor Mr. Ashford in their recently published work on British waterways, ${ }^{7}$ the question of the improvement of inland navigation is intimately bound up with that of water supply. Canal companies and water companies now compete with each other for sources of supply, and it has been recently demonstrated both by the Salmon Fisheries Commission, 1902, and the Sewage Disposal Commission, 1898 , in their third report, issued in 1903 , that the indiscriminate selection of their sources of water supply by companies and municipalities and the reckless waste of water through mining operations have seriously diminished the volume of rivers and dried up many of the springs and wells which furnish rural water supply and feed canals. The two above commissions have agreed in recommending the establishment of a central water authority for dealing with this question, as well as for controlling fisheries and checking pollution, and it is one which cannot safely be neglected in any scheme which would tend to increase the demands upon the national sources of supply in order to extend the inland navigation system. All these points have doubtless been fully considered by the Royal Commission on Canals, which is now sitting, and the report of which is expected shortly to be issued. The appointment of that body is itself the most recent and also one of the most

TOur Waterways, by Urquhart A. Forbes and W. H. R. Ashford. London: John Murray, 1906. 
important evidences of the revival of public interest in British waterways, and until its recommendations have been made public all plans for their improvement must be regarded as purely speculative. It will be evident from the foregoing necessarily imperfect sketch of some of the main features of the inland navigation system of the United Kingdom that it at all events possesses possibilities sufficient to render such an improvement eminently desirable.

\section{LIST OF AUTHORITIES.}

Stevenson, David. Principles and Practice of River Engineering, $2 \mathrm{~d}$ ed. I872. Mann, S. J., M.I.C.E. River Bars. I88I.

Lloyd, Samuel, M.I.C.E. England Needs Steam Navigation. 1885.

Jeans, Stephen, M.I.C.E. Waterways and Water Transport. 1890.

Wheeler, W. H., M.I.C.E. Tidal Rivers: Their Hydraulics, Improvement and Navigation. 1893 .

Harcourt, L. F. Vernon, M.I.C.E. Rivers and Canals, 2d ed. 1896.

De Salis, H. Rudolph. A Chronology of Inland Navigation. I897.

Thompson, W. Gordon. The Canal System of England.

Coulson, H. J. W., Forbes, U. A. The Law of Waters: Sea, Tidal and Inland. and ed. 1902.

De Salis, H. Rudolph. Bradshaw's Canals and Navigable Rivers of England and Wales. I904.

Forbes, Urquhart A., and Ashford, W. H. R. Our Waterways. 1906.

Report of the House of Lords Committee on Conservancy Boards. I877. Report of the House of Lords Committee on Thames Floods Prevention. 1877 .

Report of the Thames Traffic Committee. I879.

Report of the Commissioners appointed to inquire respecting the system of navigation which connects Coleraine, Belfast and Limerick. I882.

The Board of Trade-Returns made to, in pursuance of section 39, sub-section 2, of the Railway and Canal Traffic Act, 1888, in respect of the Canals and Navigations in the United Kingdom for 1898 .

The Board of Trade-Reports made to, under section 4I of the Railway and Canal Traffic Act, I888, in respect of the River Ouse navigation, the Kennet and Avon Canal navigation, and the London and Hampshire Canal, r8gr.

Department of Agriculture and Technical Instruction, Ireland-Banking, Railway and Canal Statistics. rgor.

Report of the Royal Commissioners appointed in 1900 on Salmon Fisheries. Ig02.

Third Report of the Royal Commission appointed in 1898 on Sewage Disposal. I903.

Ninety-ninth Report of the Commissioners of the Caledonian Canal. I904. 